\title{
Diabetic foot and its serial treatment in high-risk patients: focusing on the individual
}

\author{
(iD) Eli Ávila Souza Júnior ${ }^{1}$ \\ Raul Silva Simões de Camargo² \\ (iD) Tiago Soares Baumfeld ${ }^{3}$ \\ (D) Daniel Soares Baumfeld ${ }^{3}$ \\ (iD) Benjamin Dutra Macedo ${ }^{3}$
}

\begin{abstract}
1. Médico Ortopedista - Universidade Federal de Alfenas - Unifal, Alfenas, MG, Brasil. 2. Acadêmico de Medicina - Universidade Federal de Minas Gerais - UFMG, Belo Horizonte, MG, Brasil. 3. Médico Ortopedista - Hospital Felício Rocho, Belo Horizonte, MG, Brasil.
\end{abstract}

http://dx.doi.org/10.1590/1806-9282.66.11.1542

\section{SUMMARY}

OBJECTIVES: To assess knowledge about diabetic foot, care measures, and the importance attached to serial treatment in a group of high-risk diabetic foot patients.

METHODS: This is a cross-sectional study, carried out in a tertiary hospital, with 25 patients undergoing serial treatment for diabetic foot. The tabulation of the data occurred through the use of three methodological figures: core idea, key expressions, and the collective subject discourse.

RESULTS: It became evident that even among high-risk patients with diabetic foot, there is no complete knowledge about the definition of the disease. Despite this, all participants reported practicing daily care measures, including frequent inspection of the feet, food care, and attention to footwear. Regarding the importance of serial treatment, there was unanimous recognition of the relevance of this practice, which improves self-care discipline, optimizes the understanding of the disease, and helps to prevent progression.

CONCLUSIONS: Authentic speeches in the context of a pathology of considerable prevalence manifested, in an unprecedented way, with conceptions about its definition, care measures, and importance of serial treatment in a high-risk group.

KEYWORDS: Foot diseases. Diabetic foot. Amputation. Bioethics.

\section{INTRODUCTION}

Diabetic foot is one of the most devastating chronic complications of diabetes mellitus due to the large number of cases that evolve to amputation'. For the individual, it brings repercussions in their personal life, affecting their self-image, self-esteem, and role in their family and in society, and, if there are physical limitations, it can cause social isolation and depression ${ }^{2.3}$.
The World Health Organization ${ }^{4}$ defines therapeutic education as the training of patients and family members in the skills for the management of treatment or for special adjustments and for the prevention of complications from the disease. Its importance is recognized for the treatment of chronic diseases, such as diabetic foot, in which the patient is responsible for long-term care in order to prevent complications ${ }^{5}$. 
The results of clinical trials assessing the preventive efficacy of training diabetic patients for preventing diabetic foot lesions are not conclusive ${ }^{6}$. The failures seem to be related to the non-adherence of patients to the recommendations received ${ }^{7}$. The issue of care of the feet, from the perspective of patients, a thorough knowledge of the meaning of the disease, of care, its needs, their sufferings and anxieties can point out new directions for therapeutic education so as to improve its results.

For Minayo et al. ${ }^{8}$, qualitative research answers specific questions, considering as the object of study people belonging to a group and with a certain social condition, with a set of meanings, values, beliefs and attitudes. Exploratory research is carried out in areas in which there is little accumulated and systematized knowledge, constituting, in the first step, of a broader investigation, developed when a topic is little explored. Due to its survey nature, it does not contemplate hypotheses that may arise during or at the end of the research.

\section{METHODS}

This is an exploratory-descriptive, cross-sectional study with a qualitative approach, approved by the Research Ethics Committee of the institution.

We elected as inclusion criteria: patients with diabetic foot, a history of any previous amputation caused by diabetes (high-risk patients), undergoing serial treatment in the orthopedic center of the institution. We understood by serial treatment of diabetic foot monthly evaluations in a specialized outpatient clinic, during which the feet are inspected by a specialist who performs several procedures, such as: debridements, special dressings, and providing care instructions for feet at risk.

The study, conducted from 1 April 2019 to February 12020 included 25 patients undergoing serial follow-up.

To know and describe the considerations on serial treatment for diabetic foot, under the framework of Social Representations (SR), and the Collective Subject Discourse (CSD) method was chosen since it allows an approximation to the phenomenon under study. CDS consists of a set of procedures for the tabulation of discursive data used to obtain an understanding of a given topic. The analytical procedure was operationalized with the following steps: the selection of key expressions of each discourse, analogous to the vital tone; identification of the core idea of each key expression, building the synthesis of the content; identification of similar or complementary core ideas; the gathering of key expressions referring to the core ideas ${ }^{9}$.

We then carried out the individual interviews, using three structured questions that addressed: the concept for diabetic foot, the daily practices of care for diabetic foot, and the importance attributed to the serial treatment of diabetic foot. In addition, we characterized the sample, based on gender, age, type of diabetes (I or II), time of diabetes diagnosis, and history of amputation. Previously, the informed consent form (ICF) was signed, per Resolution no. 466/2012 of the National Council of Health.

For the data analysis, the order of the steps was strictly followed.

In the first one, in order to obtain a complete knowledge of the narratives/discourses transcribed, we conducted an exhaustive reading to build an overview and a better understanding of the discursive manifestations.

In the second one, we conducted a reading of each transcript alone, based on each of the questions in the guide.

In the third, after reading the full content of all answers inherent to each one of the three questions from each respondent, we used the instruments from discourse analysis, representing the key expressions (KEs), which are excerpts from the discourse that reveal the essence of the statement, which are found in italics or underlined. In possession of the KEs and after reading each one, we identified the core ideas (CI), which describe in the most concise and accurate way possible the meaning of each one of the discourses analyzed and of each homogenous set of KEs, which will later make up the CSD. In addition to the CI, the KEs can also refer to a methodological figure. This same procedure was carried out with all three questions.

In the fourth step, the Discourse Analysis Instrument was prepared, which accounted for, separately, each CI with their respective similar or complementary KEs.

In the fifth step, we built the collective discourse for each grouping. It was necessary to sequence the KEs of each group, organizing them into a beginning, middle and end. We adopted grammatical connectives to connect the KEs, maintaining the cohesion of discourse. 


\section{RESULTS}

The characterization of the sample is detailed in the table below:

TABLE 1. CHARACTERIZATION OF THE SAMPLE

\begin{tabular}{l|l}
\hline Gender & $\begin{array}{l}\text { Male }=88 \% \\
\text { Female }=12 \%\end{array}$ \\
\hline Age & $\begin{array}{l}\text { Maximum }=91 \text { years } \\
\text { Minimum }=39 \text { years } \\
\text { Mean }=72 \text { years }\end{array}$ \\
\hline Type of diabetes $(\mathrm{I}$ or $\mathrm{II})$ & $\mathrm{I}=8 \%$ \\
& $\mathrm{II}=92 \%$ \\
\hline Time of diagnosis & Maximum $=51$ years \\
& $\begin{array}{l}\text { Minimum }=2 \text { years } \\
\text { Mean }=18 \text { years }\end{array}$ \\
\hline History of amputation & $\begin{array}{l}\text { Toe }=44 \% \\
\text { Radial }=16 \% \\
\text { Transmetatarsal }=16 \% \\
\end{array}$ \\
& Transtibial $=20 \%$ \\
\hline
\end{tabular}

Table 2 demonstrates the core ideas and prevalences found for the three approaches.

\section{TABLE 2. CORE IDEAS AND PREVALENCES}

\begin{tabular}{l|l|l}
\hline Questions & Core idea & Prevalence \\
\hline $\begin{array}{l}\text { In your opinion, what } \\
\text { is the concept of } \\
\text { diabetic foot? }\end{array}$ & $\begin{array}{l}\text { Vulnerability to injury and } \\
\text { amputation }\end{array}$ & $40 \%$ \\
\cline { 2 - 3 } & Doesn't know & $30 \%$ \\
\cline { 2 - 3 } & $\begin{array}{l}\text { Manifestation of glycemic } \\
\text { disorder }\end{array}$ & $20 \%$ \\
\cline { 2 - 3 } & $\begin{array}{l}\text { Consequences of vascular } \\
\text { insufficiency }\end{array}$ & $10 \%$ \\
\hline $\begin{array}{l}\text { Do you practice care } \\
\text { for the diabetic foot on }\end{array}$ & Attention to footwear & $50 \%$ \\
\cline { 2 - 3 } $\begin{array}{l}\text { a daily basis? Which } \\
\text { ones? }\end{array}$ & Dietary care & $20 \%$ \\
\cline { 2 - 3 } $\begin{array}{l}\text { In your opinion, what } \\
\text { is the importance of } \\
\text { the serial treatment for } \\
\text { diabetic foot practiced } \\
\text { here? }\end{array}$ & Frequent inspection & $30 \%$ \\
\cline { 2 - 3 } & $\begin{array}{l}\text { Petter understanding of the of progression } \\
\text { disease }\end{array}$ & $40 \%$ \\
\hline
\end{tabular}

The core ideas (CI), keywords and collective subject discourse for the first approach (In your opinion, what is the concept of diabetic foot?) are listed below:

CI: Vulnerability to injury and amputation - 40\%

CSD: "Situation in which any 'small blister' becomes a wound; the wounds evolve and quickly lead to amputation; the wounds under the foot are the ones you have to look out for; well, based on the amputation I had on my foot, it is a condition that causes amputations"

CI: I do not know - 30\%

CSD: "I understand almost nothing, I take care, but I cannot say; I don't know anything about this issue; honestly, I do not know anything"
Cl: Manifestation of glycemic disorder - 20\%

CSD: "It is due to sugar; a sugar disorder in the blood causes this disease on the foot; it is related to the fact that my glucose is a bit high; the problem is the glucose, it is always "peaking"; glucose peaks lead to these complications"

$\mathrm{Cl}$ : Consequences of vascular insufficiency -10\%

CSD: "It is a deficiency of vascularization; it is a circulatory complication and from it comes gangrene; I think that the circulation is compromised, the blood is not flowing enough to the foot"

The core ideas (CI), keywords and collective subject discourse (CSD) for the second approach (Do you practice care for the diabetic foot on a daily basis? Which ones?) are listed below:

Cl: Attention to footwear - 50\%

CSD: "I'm never barefoot and aways dry my feet to prevent injuries; I am cautious with footwear not to hit it; I wear footwear in the countryside; I wear custom footwear; I always wear boots, I never walk barefoot"

CI: Dietary care - $20 \%$

CSD: "I do not eat sweets, only the ones for diabetics; balanced diet, my food is usually different from others; I don't eat sugar; controlled diet; I try to eat more natural products"

Cl: Frequent Inspection - 30\%

CSD: "I keep watch of my foot 24 hours per day; I always look in the mirror; I wear light-colored socks to notice any bleeding; I see a podiatrist to get my nails cut; I am always watching my toe"

The core ideas (CI), keywords and collective subject discourse (CSD) for the third approach (In your opinion, what is the importance of serial treatment for diabetic foot?) are listed below:

Cl: Prevent progression - 40\%

CSD: "Monitoring is essential to help in healing; I feel that in two months it will have healed; I like to carry out the control to prevent progression; I think that it is essential to take care for it not to evolve further"

Cl: Discipline in healthcare - 20\%

CSD: "Diabetic individuals are liars, always making 
up excuses, but now things took a turn for the better, now I am more disciplined; now I value it more; I pay more attention"

\section{Cl: Better understanding - $40 \%$}

CSD: "I got instruction, it enables me to know how to take care; brings more tranquility to us; you have much more control of what is happening with yourself, control of the situation; it helped me understand a bit better"

\section{DISCUSSION}

In the sample characterization, we observed that most people with high-risk diabetic foot were elderly (mean age 72 years). A survey conducted in the city of Planura, Minas Gerais, Brasil, also found that the elderly makeup most of the people with diabetic foot who attended a particular health institution ${ }^{10}$. A study performed in Ribeirão Preto, SP, presented a frequency slightly higher for males regarding diabetic patients with foot ulcers ${ }^{11}$. In that study, in which were considered patients previously amputated, the male sample was significantly greater (88\%). This finding contrasts with the study conducted at the University of the State of Pará, in which women with diabetic foot were greater in number ${ }^{12}$.

Diabetic foot is a term used to designate the various ailments which may evolve to amputation ${ }^{13}$. In this study, when we investigated the concept of diabetic foot among participants, no complete definition was observed; however, most correlated the disease with some of its characteristics, through core ideas, such as: vulnerability to injury and amputations, manifestation of glycemic disorder, and repercussions of vascular insufficiency. However, 30\% could not define anything concerning the pathology. This finding is alarming, considering these are high-risk patients already submitted to previous amputations. It is estimated that $30 \%$ to $50 \%$ of those who underwent an amputation will require additional amputations within one to three years, and $50 \%$ will die within five years from the first amputation of greater level ${ }^{14}$.

The adhesion to examining shoes before putting them on often masks the real information that, in truth, these people were open shoes, therefore, there is no need to look inside them, data that contradicts the literature recommendations, endorsed by the $\mathrm{SBD}^{15}$ and $\mathrm{ADA}^{16}$. Research has shown that, out of 22 diabetic patients participating in a study, $81.8 \%$ worn open shoes ${ }^{17}$. In a city in the interior of Minas Gerais, a percentage of $92 \%$ of diabetics wearing inadequate footwear was identified ${ }^{18}$. Among the care measures practiced by the interviewees in this study, the majority (50\%) mentioned care with the shoes worn.

Poor glycemic control facilitates the onset and development of chronic complications and increases the risk of neuropathy; however, there are no studies demonstrating a direct relationship between hyperglycemia and amputations ${ }^{19}$. Knowledge about glycemic optimization was also seen in the participants of this study (20\%), who mentioned dietary attention as a way to care for diabetic foot.

Acknowledging the value of shared responsibility and of the need for the developing autonomy and participation of diabetic individuals has the potential to improve care because of the likely positive effect of their own satisfaction in the adherence to treatment. On the other hand, patients who do not adhere to treatment have a 50-times-higher probability of having foot ulcerations and are 20 times more likely to be amputated than those who follow the guidelines correctly $^{20}$. This shared responsibility was inferred by $20 \%$ of the participants, who recognized the importance of serial treatment for diabetic foot as a way of being more disciplined.

According to the International Consensus on Diabetic Foot, people should undergo, at least, one annual examination of their feet ${ }^{21}$. For those at high risk (including those that have already been submitted to amputation), the examination should be done every one to three months, and in special conditions, even weekly. It ensures that this exam is the essential component for the proper management of this complication, upon an investigation of the protective sensation of the foot, its structure, biomechanics, circulation and skin integrity, through simple and low-cost tests. Forty percent of the respondents acknowledged that serial control is an important way of preventing the progression of the disease.

In the studies by Santos et al. ${ }^{22}$, most individuals who underwent amputations had poor metabolic control, had no access to information on preventive care, did not adhere to the clinical treatment, and had financial difficulties. In addition, amputation and limb loss have a greater impact than any other complication from diabetes, since, in addition to the loss of mobility and independence, anxiety and depression are frequent. The care for diabetic foot improves with a clearer understanding of the factors 
that lead to limb loss and a growing consensus on the various measures that must be taken regarding the foot. Forty percent of the participants of this study valued the serial treatment as a way of obtaining more knowledge about the preventive measures and practices for diabetic foot.

\section{CONCLUSION}

It was evidenced that, from a qualitative approach, that even among patients with a high risk for diabetic foot, there is no full knowledge about the definition of the disease; some expressed some understanding, while 30\% reported having no knowledge. Despite this, all participants reported practicing daily care, including the frequent inspection of the foot, dietary care, and attention to footwear. Regarding the importance of the serial treatment, the recognition of the importance of this practice was unanimous, with statements that it improves the discipline of self-care, enhances the understanding of the disease, and helps prevent its progression.

\section{Ethical Aspects}

The authors declare there are no conflicts of interest.

This work had no funding agency. Approved by the Research Ethics Committee on the Brasil Platform. CAAE 29510919.3.0000.5125

\section{Author's Contribution}

Eli Ávila Souza Júnior conceived and planned the activities that led to the study and drafting of the paper, in addition to the process of final review; Raul Silva Simões de Camargo and Tiago Soares Baumfeld interpreted the results of the study and participated in the process of the final review; Daniel Soares Baumfeld and Benjamin Soares Dutra participated in the process of final review and approved the final version.

\section{RESUMO}

OBJETIVOS: Avaliar o conhecimento sobre o pé diabético, medidas de cuidado e importância atribuída ao tratamento seriado em um grupo de alto de risco de portadores de pé diabético.

MÉTODOs: Este é um estudo transversal, realizado em um hospital terciário, com 25 pacientes submetidos ao tratamento seriado do pé diabético. A tabulação dos dados ocorreu por meio da utilização de três figuras metodológicas: ideia central, expressões-chave e o discurso sujeito coletivo.

RESULTADOS: Evidenciou-se que mesmo entre pacientes de alto risco do pé diabético, não há conhecimento pleno sobre a definição da doença. Apesar disso, todos os participantes relataram praticar medidas diárias de cuidado, incluindo inspeção frequente dos pés, cuidado alimentar e atenção aos calçados. Sobre a importância do tratamento seriado, foi unânime o reconhecimento da relevância dessa prática, a qual melhora a disciplina dos autocuidados, otimiza a compreensão da doença e ajuda a prevenir a progressão.

CONCLUSÕES: Discursos autênticos no âmbito de uma patologia de considerável prevalência manifestaram, de forma inédita, as concepções sobre definição, medidas de cuidado e importância do tratamento seriado em um grupo de alto risco.

PalaVRas-ChaVe: Doenças do pé. Pé diabético. Amputação. Bioética.

\section{REFERENCES}

1. Gamba MA. Amputações por diabetes mellitus: uma prática prevenível? Acta Paul Enf. 1998;11(3):92-100.

2. Rezende KF, Nunes MAP, Melo NH, Malerbi D, Chacra AR, Ferraz MB. Internações por pé diabético: comparação entre o custo direto estimado e o desembolso do SUS. Arq Bras Endocrinol Metab. 2008;52(3):523-30.

3. Coelho MS, Silva DMGV, Padilha MIS. Representações sociais do pé diabético para pessoas com diabetes mellitus tipo 2. Rev Esc Enferm USP. 2009;43(1):65-71.

4. World Health Organization. Therapeutic patient education. Copenhagen: WHO;1998.

5. Nair KM, Dolovich LR, Ciliska DK, Lee HN. The perception of continuity of care from the perspective of patients with diabetes. Fam Med. 2005;37(2):118-24

6. Valk GD, Kriegsman DM, Assendelft WJ. Patient education for preventing diabetic foot ulceration. Cochrane Database Syst Rev. 2001;(4):CD001488.
7. Lutfey KE, Wishner WL. Beyond "compliance" is "adherence". Improving the prospect of diabetes care. Diabetes Care. 1999;22(4):635-9.

8. Minayo MCS, Deslandes SF, Gomes R. Pesquisa social: teoria, método e criatividade. Petrópolis: Vozes; 1994.

9. Lefévre F, Lefévre AMC, Teixeira JJV. O discurso do sujeito coletivo: uma abordagem metodológica em pesquisa qualitativa. Caxias do Sul: EDUCS; 2000 .

10. Rodrigues AN, Szymaniak NP, Andrade Sobrinho |. The role of dermatosis on diabetes patient's quality of life. Cienc Saude Colet. 2010;15(Suppl 1):1325-32.

11. Martin IS, Beraldo AA, Passeri SM, Freitas MCF, Pace AE. Causas referidas para o desenvolvimento de úlceras em pés de pessoas com diabetes mellitus. Acta Paul Enferm. 2012;25(2):218-24. 
12. Palmeira MM, Silva LL, Sousa RM, Cordeiro CRG. Perfil epidemiológico dos pacientes diabéticos atendidos no Serviço de Diagnóstico em Cardiologia da Universidade do Estado do Pará. Rev Bras Med. 2011;11(2):29-32.

13. Amaral Júnior AH, Amaral LA, Bastos MG, Nascimento LC, Alves Ml, Andrade MA. Prevention of lower-limb lesions and reduction of morbidity in diabetic patients. Rev Bras Ortop. 2014;49(5):482-7.

14. Armstrong DG, Cohen K, Courric S, Bharara M, Marston W. Diabetic foot ulcers and vascular insufficiency: our population has changed, but our methods have not. J Diabetes Sci Technol. 2011;5(6):1591-5.

15. Sociedade Brasileira de Diabetes. Tratamento e acompanhamento do diabetes mellitus. Diretrizes da Sociedade Brasileira de Diabetes. São Paulo: Sociedade Brasileira de Diabetes; 2011.

16. American Diabetes Association. Standards of medical care in diabetes: 2011. Diabetes Care. 2011;34(Suppl 1):S11-61.

17. Morais GFC, Soares MJGO, Costa MML, Santos IBC. O diabético diante do tratamento, fatores de risco e complicações crônicas. Rev Enferm UER]. 2009;17(2):240-5.
18. Carvalho RP, Carvalho CP, Martins DA. Aplicação dos cuidados com os pés entre portadores de diabetes mellitus. Cogitare Enferm. 2010;15(1):106-9.

19. Assumpção EC, Pitta GB, Macedo ACL, Mendonça GB, Albuquerque LCA, Lyra LCB, et al. Comparação dos fatores de risco para amputações maiores e menores em pacientes diabéticos de um Programa de Saúde da Família. J Vasc Bras. 2009;8(2):133-8.

20. Caiafa SS, Castro AA, Fidelis $C$, Santos VP, Silva ES, Sitrângulo |r C|. Atenção integral ao portador de pé diabético. J Vasc Bras. 2011;10(4, Supl 2):1-32.

21. International Working Group on the Diabetic Foot. International consensus on the diabetic foot and practical guidelines on the management and prevention of the diabetic foot [DVD]. Brussels: International Diabetes Federation (IDF); 2011.

22. Santos ICRV, Sobreira CMM, Nunes ÉNS, Morais MCA. Prevalência e fatores associados a amputações por pé diabético. Cien Saude Colet. 2013;18(10):3007-14. 